\title{
Historical Research on French Diplomacy During World War
}

\author{
Shijiazhuang No.24 high school, Shijiazhuang, Hebei, China \\ *Corresponding author. Email: vetotashann@gmail.com
}

Zexu Han

\begin{abstract}
France was a great power in modern Europe and the world. During the First World War, France's world status was weakened. But in Europe, France's position was not weakened, but was greatly strengthened by the defeat of Germany and the collapse of the Austro-Hungarian Empire. This not only greatly improved France's political and economic status in Europe, but also made it the most powerful military power in Europe. But only five or six years later, France began to lose this advantage, and soon after the Second World War broke out, it was destroyed by Germany. The historical process of France's transformation from superiority to inferiority during the two world wars is certainly multi-faceted, but from a diplomatic perspective, its historical lessons are worth learning today.
\end{abstract}

Keywords: French diplomacy, world wars, lessons of history

\section{INTRODUCTION}

After World War I, France's European diplomacy has always pursued two goals: national security and European hegemony. The pursuit of national security is undoubtedly justified, but in the pursuit of national security, France has great imperialist ambitions, that is, trying to take advantage of the defeat of Germany and weaken Germany to the greatest extent. Not only does France require Germany to pay huge indemnities, but it also wants to dismember Germany in order to establish its own hegemony in Europe. In dealing with the German issue, it focused on reflecting French hegemony ambitions.

\section{BRITAIN AND THE UNITED STATES UNITED AGAINST FRANCE'S PLAN}

The territorial issue and the issue of compensation are at the core of dealing with the defeat of Germany. On these two issues, France has acted on the main objective of establishing its hegemony in Europe. The French plan seriously damaged the national interests of Germany, making it difficult for Germany to accept; at the same time, the French plan also conflicted with the imperialist interests of countries such as Britain and the United States. As far as the United States is concerned, it was the country that made the most money in the First World War. It originally wanted to establish its own hegemony in post-war Europe and the world. Of course, it was unwilling and would never see France establish hegemony in Europe. Without obstruction. As for Britain, it is an ancient colonial empire with global interests, but its foothold is still in Europe. The purpose of Britain is to not only weaken Germany as its competitor, but also maintain a Germany with a certain power to counter France, so that it is conducive to its own control of European affairs. Because of this, Britain and the United States united against France's plan.

On June 28, 1919, representatives of various countries participating in the Paris Peace Conference signed the "Versailles Peace Treaty" in Paris. This treaty satisfied most of France's requirements and gained many benefits. In particular, the recovery of Alsace-Lorraine and the acquisition of the mining rights of Thrall coal mine laid the economic foundation for France to dominate Europe. But the Treaty of Versailles has a big drawback, that is, it has not formulated a clause that can truly eliminate German militarism. The peace agreement stipulates that Germany can retain 100,000 officers and soldiers and stipulates the dismantling of military fortifications on the German West Front, but it retains the German East Front. The secret terms of the peace treaty also obliged Germany's troops on SovietRussian territories to stay on until the troops of the Allied Power succeeded them. All this reveals the Allied imperialist hatred of Soviet Russia and the anti-Soviet conspiracy they are stepping up.[1]

The Treaty of Versailles brutally trampled on Germany's basic rights and interests, thus generating resentment in the hearts of the Germans; Europe was artificially divided into many small pieces, which also made it more difficult for the national principles to be applied fairly, which left the divided nations Endless pain and scars were laid, and a place for ambition and revenge was prepared. In 1918, President Wilson of the United States declared that he wanted to achieve "perpetual peace", but in Europe after the signing of the Versailles Treaty, the dawn of "permanent peace" never appeared. In comparison, the French Marshal Fu Xu's statement is more in line with European reality. He said: "This is not peace. This is a two-year truce." In fact, in the two decades after the Treaty of Versailles, not only did there not be real peace, but even the "truce" was continuously destroyed. It's just that conflicts are limited to a certain range, and some conflicts take the form of unarmed ones. 
British economist Keynes, when he talked about the dispute between European powers since the second half of the nineteenth century, once angrily condemned the Germans, but also condemned the British and French. He said: "Germans are violent and self-serving, overthrowing the foundation of life that we all established. But the spokespersons of the British and French people used the Versailles peace agreement to take the risk of completing the Germans and beginning to destroy Europe." The country also said that if Britain and France "abuse their temporary victory to destroy Germany and Austria-Hungary, which have now yielded, then they will lead to their own destruction." History has proved Keynes in its subsequent development Is right. When Germany revived, it punched its iron fist on France. This is exactly what he wants to dominate, which is a disaster to himself. After the signing of the Versailles peace treaty, France gained an advantage in Europe within a certain period of time. But France is not satisfied with this. After 1919, it also tried its best to make Poland, Czechoslovakia, Romania, Yugoslavia, Belgium and some other countries in Eastern, Central and Western Europe dependent on their own status. Between 1919 and 1923, France has successively entered into military alliances with Belgium, Poland, Czechoslovakia, Romania, and Yugoslavia. With the instigation of France, Czech, Romanian, and other small countries in Eastern and Central Europe have also entered into military alliances with each other. In this way, the small allies with a population of 40 million were born. The small Allies not only established military alliances with each other, but also with France. The establishment of the small Allies and the establishment of ties with France is because they want to help each other to deal with Germany together to prevent the re-aggression of Germany. However, the establishment of the small Allies further strengthened France's position in Europe. In essence, it is still a continuation of France's pursuit of hegemony in Europe. However, when France's alliance on the European continent was handy, its political relations with other major powers were estranged, especially with Britain. At that time, the relationship between Britain and France was very tense, and Italy and France also had a lot of disputes, because Italy also wanted to establish its own power in Yugoslavia and Romania. But of all the contradictions between France and other capitalist powers at that time, the contradiction between Britain and France was the main one. After the war, Britain used every means to prevent France from becoming stronger in Europe and to prevent Germany from being excessively weakened, but all British efforts had little effect, which made the contradiction and struggle between Britain and France increasingly acute. By 1923, the opportunity for Britain to crack down on France had finally arrived. This is the new crisis in Europe caused by the German compensation problem in 1923.[2]

\section{FRANCE AND THE MUNICH AGREEMENT}

After the signing of the Muenich Agreement, Britain and France once declared that "this is the peace of our time." But history has proved that the Muenich Agreement did not bring peace to Europe, nor did it reach the point where the British and French countries would lead the German Fascist disaster. the goal of. On the contrary, it led to the West. On September 1, 1939, Hitler disregarded the British-Poland guarantee agreement signed a week ago, and France had just reiterated its previous alliance obligations to Poland. It violently invaded Poland with 700,000 troops from north to south, and Britain and France were forced in September. The war was declared on the 3rd, and World War II was first launched between Germany and Britain and France. This is a historical tragedy. It is the result of the suffering of the British and French tigers, which ultimately led to the annihilation of France.[3]

The European Federation proposed by France also conflicts with the interests of the United Kingdom. Since the 1920s, Britain has tried to prevent France from becoming powerful. Now, when France has been weakened, how can it allow the resurgence of French hegemony? In order to fight against France, Britain put forward a counter-recommendation, that is, the establishment of an organization United States of America. The United States of America proposed by the United Kingdom to be organized is called the "United States of Europe". In fact, it includes not only European countries, but also European colonies. And Britain is the country with the most colonies, so that Britain can establish its leadership in the United States of Europe. The British plan was opposed by both France and the United States. Because the United States is afraid of the emergence of a unified Europe, it will weaken its political and economic influence that Europe has expanded after the war. As for Germany, it neither agrees with the British plan nor the French plan. If Germany wants aggression and revenge, it naturally needs freedom of movement. In this way, both the French plan and the British plan have to be shelved. Later, when Hitler's Third Reich rose in Europe, the danger of a new world war further increased, and the center of this danger was shifting from the Far East to Europe. Under this new situation, the peace forces led by the Soviet Union at that time, in order to protect peace and stop aggression, since 1933, they have put forward the slogan of fighting for collective security and collective sanctions against aggressors. A decision was made on joining the League of Nations, and officially joined the League of Nations on September 16, 1934. However, while the Soviet Union was actively engaged in collective security diplomacy activities, France acted alone, following a different path. In February 1934, Bartou, the Minister of Foreign Affairs of the French Dumaigue government, was keen to piece together a regional group, that is, to prepare an international agreement called "Eastern Europe (or Eastern Rogano Convention)" to establish the security system envisaged in France. According to France's plan, this convention should not only include the small allies and the small Baltic states, but also include some big countries 
such as the Soviet Union, Italy, and Germany. It is clear that France's goal is still to put the envisaged security system in its own hands. The difference is that it does not exclude the Soviet Union, nor does it exclude Germany and Italy. Despite this, the Soviet Union enthusiastically supported Bartu's proposal to prevent Germany's foreign invasion and expansion. However, the United Kingdom opposed the signing of the Oriental Convention because the United Kingdom was extremely reluctant to assume new obligations to Eastern Europe. Only later, because of the great pressure from France and Bartu himself, did Britain have to agree, but also proposed that the Oriental Convention should not be signed into an alliance treaty, and that all rights and obligations under the treaty should be equally borne by the contracting parties. As for Germany, it does not want to be bound at all, so it has categorically refused to participate in this convention from the beginning. In addition, due to the mistrust between Poland and the Soviet Union, and various other reasons, the plan of the "Eastern Rogano Convention" ended in vain.[4]

One year later, in May 1935, due to the further deterioration of the international situation, the German vengeance that threatened France continued to grow, and French public opinion was increasingly determined to conclude an agreement with the Soviet Union, France only in May 1935 On the 2nd, a mutual assistance treaty was concluded with the Soviet Union. On May 16, the same year, the Soviet Union and Czechoslovakia also concluded a mutual assistance treaty. However, neither the French-Soviet Treaty nor the Soviet Union Treaty have played their role. This is firstly because the French-Soviet Treaty has not been approved by the French parliament for a long time, and when the Soviet-Jewish Treaty was signed, Czech Republic provided a conditional condition, that is, only when France performed its when it is an obligation, Su Jie's mutual assistance obligation is effective. Now that the FrenchSoviet Treaty has not been approved by the French Parliament, the Soviet Union Treaty is like waste paper. The French-Soviet Treaty and the Sujee Treaty did not play their due role. This fault is entirely in the French side. The Treaty of Soviet Union, especially the French-Soviet Treaty could have become a turning point in the history of European international relations and a cornerstone in the establishment of the collective security cause in Europe, but they did not play such a role.[5]

France's plan to oppose Soviet collective security, especially its unwillingness to unite with the Soviet Union, is fundamentally the most dangerous to France. Although Hitler publicly announced that he would attack the Soviet Union, but in his life, there are often cases of east and west, and Hitler is playing with this trick. History proves that France is at a turning point, doing its own thing, cocooning itself, binding its hands and feet, and future tragedies are waiting for it.

Due to a series of mistakes in French-European diplomacy, by the second half of the 1930s, France was in a more difficult position. First, the comparison of power between France and Germany has further changed in favor of Germany but not France. Germany has stepped up preparations for a new war, expanded its military preparations, and brought the national economy into the path of militarization, thereby greatly stimulating its national economy and increasing its economic and military strength. By 1938, Germany's steel production had exceeded the sum of Britain and France, while at the same time, France's strength was declining. The proportion of French industrial production in the capitalist world's heavy industry sector fell by 3\% in 1937 compared to 1930.[6]

\section{THE APPEASEMENT POLICY OF FRANCE AND BRITAIN}

Because of its weak status, France cannot consider fighting against Germany again without the support of its allies. The invasion of 1914 and the heavy casualties during the war all made the French feel terrified. In view of the fact that France's industry and population are not as good as Germany, France must not venture to fight Germany alone without a firm guarantee of support from allies. In this way, France's policy of appeasement following the British has become a need for diplomatic struggle.[7]

What are the consequences of France following Britain? In a nutshell, it is the fate of the tiger's suffering and its own destruction. On March 7, 1936, the fledgling Germany could not wait to strike the Caiin Demilitarized Zone with lightning, tearing the Rogano Convention in one fell swoop. This action of Germany is an open challenge to the European region where Britain and France are vital, but Britain and France have not taken any resistance action. France did not move, and in July of the same year, German and Italian fascists armedly interfered in the Spanish civil war and supported the fascist Franco rebellion against the Spanish Popular Front government. This was yet another war step taken by Hitler to attack Britain and France. By controlling Spain, Germany and Italy will be able to cut off the British transport line in the Strait of Gibraltar and put France: the country on the back. However, under such a serious situation in which Britain and France are facing the enemy, they believe that the German and Italian armed interference in Spain and the subversion of the Spanish People's Front government are a manifestation of the German and Italian anti-Bolshevikism's firm attitude. They can use this to lead the disaster to the aggression. The spearheads of the writers were directed at the Soviet Union in the east to escape their fate. On September 29, 1938, the "Municipal Agreement" for the sale of Czechoslovakia planned by Britain and France was finally released. The agreement roughly restricted Czechoslovakia to cede Sudetende and the southern region bordering Austria to Germany within twelve days. In this way, under the appeasement of Britain and France, Hitler took away 11,000 square kilometers of land and 3.6 million people in Czechoslovakia without any effort. In March 1939, Hitler further occupied Czechoslovakia.[8] 


\section{CONCLUSION}

Europe is the source of the two world wars. It used to be and is still the focus of imperialist contention. The lessons of French-European diplomacy during the two world wars, especially in the second half of the 1930s, the historical lesson that it followed the British and suffered from a tiger is worth learning deeply from all countries in the world. In today's situation of Soviet and US hegemony, especially Soviet social imperialism has become the most dangerous source of warfare in contemporary times. It is of great practical significance to learn such historical lessons.

\section{REFERENCES}

[1] Zhang Wenmu. Historical Study of Toynbee and British Postwar Foreign Policy[J]. World Economy and Politics, 2011, 000(003):4-43.

[2] Jiang Hongchen. Reasons for the victory of Charles de Gaulle's resistance movement[D]. Henan University, 2007.

[3] Jiang Jie. The "Free France" Movement in Shanghai (1940-1942)[J]. Shi Lin, 2016(5): 1-16.

[4] ME Law. Legislation Research on the Promotion Law of Cultural Industry Development[J]. Sdfxy.sxu.edu:cn.

[5] Jin Longyun. The US Foreign Relations Commission and the US Participate in the Second World War[J]. Teaching History (Second Half Monthly), 2010.

[6] Administrative Litigation, Conclusion. A Comparative Study on the Nature of Administrative Litigation in France, Germany, Britain and America[J]. Judicial Review.

[7] Li Tie, Zhang Xushan. The historical conditions and evaluation of French Yearbook School[J]. Journal of Northeast Normal University, 1995(01):31-35.

[8] Li Tie, Zhang Xushan. The historical conditions and evaluation of French Yearbook School[J]. Journal of Northeast Normal University, 1995(01):31-35. 